\title{
RESEARCH NOTE: JOB SATISFACTION AND WORKING FROM HOME IN ROMANIA, BEFORE AND DURING COVID-19
}

\author{
DANA IOANA ȚĂLNAR-NAGHI
}

\begin{abstract}
$B$ ased on ICTs development, telework is a rapidly changing phenomenon (Eurofound, 2017) and has provoked many debates on how it influences people's lives (Allen, Golden and Shockley, 2015; Golden, 2009), allowing people to work from anywhere and anytime via laptops, tablets, and smartphones (Maitland and Thomson, 2014). The COVID-19 outbreak accelerated social change and led to a forced entry of entire segments of the workforce into telework. The change was steep in particular for countries with a lower pre-pandemic incidence of working from home, such as Romania. Using longitudinal data from an original series of surveys (Voicu et al. 2020) carried out in 2018 and during the Spring 2020 lockdown in Romania, the paper aims to explore the job satisfaction of those working from home in relation to work-life boundaries, before and during the quarantine period. Findings are useful for a deeper understanding of how new work arrangements influence tele-workers' perceptions of their quality of life. Results indicate that while before the pandemic, the job satisfaction of those working from home was increasing with the age of the respondent (the younger being more satisfied with working from home), that trend changed during quarantine, and job satisfaction increased significantly for people over 40. Additionally, working more hours before the pandemic is associated with lower job satisfaction scores during COVID-19 quarantine.

Keywords: work from home; job satisfaction; WLB, pandemic; teleworkers.
\end{abstract}

\section{WORKING FLEXIBLE IN THE DIGITAL AGE BEFORE AND DURING THE COVID-19 PANDEMIC:}

In recent decades we have witnessed a decentralization of labor that has been allowed both by technological advancements and as an inherent premise of human capital development. Improving the quality of people's life has enabled more flexible work arrangements, with various options for personal development, and decreased the number of working weeks, days, and hours (Greenhaus et al. 2003; Gambles et al. 2006; Voicu 2015). The fast growth of digital technology has made

Address of the corresponding author: Dana Ioana Țălnar-Naghi, Research Institute for Quality of Life, Romanian Academy, Calea 13 Septembrie, nr. 13, sector 5, Bucharest, e-mail: dana.naghi@iccv.ro. 
it possible to implement these options. Therefore, the digital age has attracted a huge wave of social change and has also brought many changes in people's professional lives (Allen, Golden and Shockley 2015). This comes with a series of transformations and alternatives that redefine the social in all its aspects. Blurring the boundaries of space and time has enabled the emergence of new working arrangements, such as home-based telework, traditionally the most common type of remote e-working. This new alternative was increasingly being embraced as a functional tool to reduce physical mobility as commuting, while still pursuing unhindered economic growth (Hynes 2014). Telework, working from home, working remotely define an entire space of work practices that involve doing economic activity from home. Given the interest of this paper in consequences of such arrangements, I use the terms as being equivalent, despite the slight differences among them.

Working at a distance enables people to choose more individualized spending time options and articulates their lifestyles on a structure of values and attitudes much more focused on the individual's choice. The change also entered people's homes, hence their living spaces (Wight and Raley 2009), where telework redefines the domestic tasks (Hilbrecht et al. 2008), household roles (Kurowska 2018) and ways of spending time within the family. Such working rearrangements greatly challenge the balance between work and family life. Therefore, home-based work (HBW) is broadly defined as any type of paid work conducted from home (Crosbie and Moore 2004) and is the most known type of telework (the latter term allows working from anywhere (Maitland and Thomson 2014)).

Despite the increasing use of ICTs before the COVID-19, teleworking was only slowly spreading in the EU. According to the 2018 European Labour Force Survey, at the level of all the EU (28) countries, only 5\% of the labour force worked from home 'usually', and around 10\% 'sometimes'. In Romania, the sum of corresponding percentages was below $1 \%$. As a result of the first pandemic strike, Eurofound' early estimations from spring 2020 suggested that nearly $40 \%$ of the EU workers have started working from home, in Romania the percentage reaching $24 \%$. The previous experience is valuable for the actual use of telework, which already varied enormously before the COVID-19 crisis, both across countries, and within the most teleworkable sectors. The European statistics' outlook is important to be acknowledged, for a better understanding of the fast transition toward a forced telework for an impressing number of people who started to work from home, triggered by the COVID crisis. The main differences in the prevalence of telework can be seen not by sectors but by country. Nevertheless, the asymmetries within the same category of sectors are enormous. For instance, Northern Europe showed the largest growth of telework which means probably a smoother transition than in Southern Europe. A recent JRC study (Fana et al. 2020) provides evidence that the prevalence of telework in the less teleworkable sectors in the Netherlands or Finland is significantly higher than in the teleworkable sectors of Italy or Spain. 
Adding the COVID-19 pandemic context thus made working from home even harder to be managed. Eurofound's e-survey, "Living, working and COVID19 ", provides strong evidence of the impact of the pandemic on people's lives. The survey was fielded online with two rounds of data collection: one in April, when most of the EU countries were in lockdown, and the second one in July, when economies were slowly re-opening. Findings succeed to capture the pandemic 'effects for the way people live and work across Europe, covering a range of topics including "employment status, working hours, work-life balance, level of teleworking, job security, job quality and experiences of working from home". The report shows that social and economic inequalities have sharpened as a major effect of the COVID-19 crisis. The unemployed and young people "are emerging as some of lockdown's biggest losers who report the lowest levels of wellbeing, despite some improvement since the onset of the pandemic". Another visible trend is that of deepening gender disparities. Recent studies show that during COVID-19 a gender gap is present (Feng and Savani 2020). Women experienced a disproportionate impact, being less optimistic about their professional future than men - this gap widening further between April and July. In particular, young women are more likely to lose their job than men. The work - life balance has been also affected more for women than for men, in terms of reduced working hours, possible due to the burden of care responsibilities which increased for them during the pandemic. (Eurofound 2020). The mainstream literature debates tend to focus on the positive effects of home-based work (HBW) and work-life balance (WLB), which could mean an increasing perception of work-related wellbeing among teleworkers. (Aguilera et al. 2016; Morganson et al. 2010; Maruyama et al. 2009; Hilbrecht et al. 2008; Hislop and Axtell 2007, 2009; Crosbie and Moore 2004; Sullivan and Lewis 2001). Furthermore, home-based job satisfaction sources have the potential to be positively related to individuals WLB and subjective wellbeing (Caillier 2012; Virick, DaSilva, and Arrington, 2010; Golden and Veiga, 2005; Van Horn et.al. 2004; Diener, Oishi, Lucas 2003). The analytical framework I propose employs a subjective approach to measuring job satisfaction, in line with previous studies on the impact of HBW on WLB. In this regard, I chose to measure the impact of HBW effects based on Romanians' perceptions of their job satisfaction over two periods of time before and during the COVID-19 pandemic.

Within the flourishing landscape of research related to working from home, this study contributes to the literature by acknowledging two advantages. First, original results are expected to derive from the capability to use panel data to compare the situation before and during COVID-19 pandemic. The change was fast and using panel data to observe it offers the advantage of understanding the new work arrangements and how one can intervene to ease this transition. Secondly, it enables to see through comparisons if job satisfaction was conditioned by prepandemic patterns of working (from home/ office). This offers an understanding on how past experiences smoothen or not the transition and coping with pandemics 
and can be converted in lessons for eventual future pandemics or similar collective experiences. The aim of this research note is to describe how people who used to work (also) from home before and during the pandemic succeeded to maintain the balance between various aspects of work and personal life, with a focus on job satisfaction, as overall indicator for consequences of the impact of HBW on WLB.

Working from home in pandemic times in a society that just started to experience remote working is under-documented and cluttered with mixed evidence on negative and positive outcomes. Filling this niche with new empirical data is the main aim of this paper. I employ original longitudinal data on how Romanians manage to work from home, collected through an online survey called WFH, conducted in two waves, before and during the pandemic. The major advantage is that WFH enables comparisons between the two moments in time and allows inspecting relations between variables of great interest for the analyzed topic. Although the samples are not probabilistic, the collected data provides information about who some of those who are working from home are and allows testing the relationship with different control variables. Overall, results are useful for a deeper understanding of how new work arrangements influence tele-workers' perceptions of their quality of life, particularly in a society that experienced little exposure to working from home before the COVID-19 outbreak.

Findings revealed that job satisfaction for respondents from WFH samples was similar as compared to the estimate resulting from the national sample in 2016 (EQLS). Among those working from home, the amount of work is a game changer, being both an increaser (before pandemic) or a source of decrease for job satisfaction. During the lockdown, the effects deepen in the case of working over 40 hours per week, which strongly hinders job satisfaction of those working from home. The job satisfaction of those working from home occasionally increased, depending on being in a couple, weekly working hours (the more they had to work, the higher was their job satisfaction), and having a dedicated working space at home. Women proved to be less satisfied than men, household size had a negative effect, university graduates were more dissatisfied working from home. In terms of age, older respondents felt less satisfied with their WFH before pandemics, but the relation changed, and young adults along with those over 50 were more satisfied during COVID-19 lockdown. For both waves, the job satisfaction of those who work from home was not influenced by income, marital status, or number of children.

The structure of the remaining paper is as follows: the next section provides a theoretical overview about how previous studies linked the positive and negative effects of WFH to WLB. Then, I conceptualize "job satisfaction" as being central in the literature on working from home (Judge and Ilies 2004; Shamir and Salomon 1985). A brief description of data and methods documents how changes related to work - life boundaries influence the perceived job satisfaction. In the end, I discuss implications for further research and policy, as well as for employers and teleworkers. 


\section{WORKING FROM HOME AND JOB SATISFACTION SEEN THROUGH THE LENSE OF WORK - LIFE BALANCE}

Telework is an ambivalent concept through its consequences, previous studies linking the positive and negative effects of HBW to WLB and suggesting that "one size doesn't fit all" (Charalampous et al. 2018, 18). Even if the practice of working remotely has sparked many debates of how it influences people's life, most of the recent studies affirm that home-based job satisfaction sources are positively related to work - life balance. Working remotely (particularly working from home) was considered a favorable solution for a better reconciliation between an individual's professional and private life, due to its flexibility potential (Powell and Craig 2015). The initial WLB definitions have been extended to include important dimensions of individuals' lives, even those beyond family life (e.g., leisure time, social relations, personal time), but also took into account all their life's circumstances, regardless of their family situation. Previous research suggests that there is a strong association between HBW and WLB, allowing teleworkers to combine work and family responsibilities while having more time for family and leisure, saving time from commuting to work (Powell and Craig 2015; Crosbie and Moore 2004; Felstead et al. 2002).

Some authors have found that working from home comes with its own set of negative consequences. Although working from home has been promoted as an option with increased flexibility for employees, allowing a better WLB to be achieved, an associated risk may be the privacy capitalization by professional life, thus leading to conflicts between the two spheres of individuals' lives (Aguilera et al. 2016; Hilbrecht et al. 2013). The flexibility gained from these work practices can increase the stress level of individuals, because they fulfill their professional and personal roles in the same space (Crosbie and Moore 2004; Powell and Craig 2015). Also, the pressure of household members when they must choose between different tasks and responsibilities coexist in the same housing space (Tietze and Musson 2005; Tietze and Nadin 2011; Kurowska 2018). Those effects were translated into decreased productivity and lower job satisfaction, under the influence of family proximity or time spent on other unpaid activities (Eddleston and Mulki 2015; Saltmarsh and Randell-Moon 2015). Strengthening the boundaries' permeability between work and family, by means of multitasking, lead to increased conflicts between work and family dynamics (Hartig et al. 2007; Marsh and Musson 2008; Russell et al. 2009; Sullivan and Lewis 2001; van der Lippe and Lippényi 2018; Kurowska 2018).

A more up-to-date systematic literature review about how e-working remotely is linked to knowledge workers' work-related wellbeing is provided by the great work done by Charalampous et al. (2018). The review provides a critical overview of qualitative, quantitative and mixed-methods research (a total of 63 research studies), which all have analyzed the association between remote e-working, and at 
least one of five dimensions of wellbeing at work (affective, cognitive, social, professional and psychosomatic). Evaluating the studies which were considered in this research, scholars have not yet reached the consensus that telework is indeed beneficial for all employees' wellbeing. While growing evidence of the effects of telework associated with affective, social, and professional dimensions accumulates, there are few findings on its cognitive and psychosomatic effects. Although the research suggests there is an existing positive focus within the literature, there are some remote e-work negative aspects highlighted in this review. The abovementioned review tries to shed light by an evaluation of "existing empirical evidence on the association between flexible working practices (including remote e-working) and employee wellbeing", by proposing a multidimensional model of analysis (Charalampous et al. 2018, 1). The review employed the "remote eworker" as an umbrella term being specifically focused on knowledge workers, that have the greatest chance to work remotely, away from the conventional office, and the opportunity to greatly use the ICTs for accessing their work. This systematic review has created a multi-level search strategy, initially from literature reviews and keywords collection, after which a search protocol was established. With the help of this protocol scientific journals within socio-human sciences coming from seven electronic databases were identified, according to the publication limits (had to be published between 1995 and 2017), written in English and peer-reviewed. Based on extracted data, data selection and coding according to a Meta-Analyses for protocol (PRISMA-P 2015), and other specific methodological and screening tools, the results were presented as a narrative synthesis of all the final 63 selected studies.

Overall, HBW researchers cannot yet rely on clear evidence that flexible working practices are indeed beneficial for individuals' wellbeing or their work -life balance. But studies showed that teleworking is associated with greater job satisfaction, even if it does not vary significantly from office work. Sources of satisfaction of those who work remotely, particularly of those who work from home, correlate positively with WLB. Thus, those who are more satisfied with working from home are also those who manage to achieve a better balance between professional and family life. Multiple mechanisms are behind this relation. Ter Hoeven and Van Zoonen (2015) argue that the more flexibility one has with respect to working space, the more one will experience increased WLB, job autonomy and effective communication, which means greater wellbeing. Nevertheless, counterexamples show that individuals who work remotely have a high probability of intensifying their work (Kelliher and Anderson 2010; De Menezes and Kelliher 2011) - engaging in the exchange of e-mails out of the working hours, and so reporting longer working hours, which made it harder to "switch off" one's working time. These behaviors can lead to an ineffective work strategy, whereby some individuals may embrace overworking to compensate for the permitted flexibility, that may be associated with the feeling of guilt and 
intolerance to stress (Moe and Shandy 2010; Chesley 2010, 2014). Consequently, telework may become unfavorable due to the blurred home - work boundaries (Tieze and Musson 2005), translated into decreasing levels of wellbeing, a poor health and emotional exhaustion (Sardeshmukh, Sharma, and Golden 2012).

Even if home-based work may potentially link to individual's wellbeing, increasing their WLB, it is still debated in the literature in opposing ways. Previous research suggested that teleworkers gradually working in more flexible ways will increase both their work productivity and job satisfaction, to achieve a better balance between work and family demands (Bentley and Yoong 2000; Pinsonnault and Boisvert 2001; Parasuraman and Greenhaus 2002). Traditionally, the concept of job satisfaction has been most studied in the literature, as Charalampous retrieved in her systematic review "a strong evidence for a positive association between remote e-working and job satisfaction" (Gajendran and Harrison 2007; Hornung and Glaser 2009; Kelliher and Anderson 2010; Vega, Anderson, and Kaplan 2015; Charalampous et al. 2018, 14.). Previous alternative research considered job satisfaction both a cognitive component of wellbeing, but also an affective state. Brief and Weiss (2002) suggested that it is not enough to know how individuals feel about their job, but also it is necessary to know how they evaluate their job (Van Horn et al. 2004; Diener, Oishi, Lucas 2003). An interesting curvilinear relation was found between working remotely and job satisfaction under certain conditions (Golden and Veiga 2005; Virick, DaSilva, and Arrington, 2010; Caillier 2012): a greater job satisfaction gradually increased with telework, but after 15 working hours it decreased and stagnated. Findings are important, because they move further the research, and show that job satisfaction is linked to the amount of exposure time to remote work. Moreover, ideally conditions for telework as a favorable tool could be choosing it as a part-time work practice, maintaining face-to-face interactions, and still having a large flexibility.

Within this mixed landscape of evidence regarding subjective wellbeing and working from home, this research brings new insights from a society that heavily increased WFH during pandemic times. Romania had a low rate of working from home (about $1 \%$ in 2018, according to Eurofound, 2020) as compared to other European societies. Forced by the pandemic, beginning in March 2020, the prevalence of home-based working in Romania increased to $24 \%$, as Romania was an early adopter of the social distancing measures, considering the rapid spread of COVID-19, compared to other Western societies. This creates a fertile environment to study the effects of sudden changes in work patterns.

The existing literature connects job satisfaction to various job outcomes, including income or worked hours. The COVID-19 pandemic poses supplementary stress and raises questions on whether the number of hours worked could produce an effect on job satisfaction. It makes children both a resource for satisfaction and a stressor. In an age when job security was rumored to be precarious, the number of worked hours should help increasing satisfaction, but also decreasing it due to 
stress brought to WLB. Consequently, the number of working hours before and during the COVID-19 quarantine are expected to have different outcomes on job satisfaction scores. Educational attainment is likely to be among them. Marital status and the number of dependent children could influence job satisfaction, by easing or adding an extra-load of house chores that impact on the available time of the teleworker. Having a dedicated working space at home structurally shapes the available space for working and may hinder or boost job satisfaction. All these factors depict constraints intrinsic to work (working time), capabilities (education), personal time (family), and space (availability of a dedicated place to work from home). They can have different effects being analyzed comparatively before and during the pandemic. With all these mechanisms in mind, we have reasons to test alternative hypotheses for the presence of either positive or negative effects of all the factors considered.

\section{DATA AND METHODS}

Using Romanian longitudinal data, this paper aims to explore the job satisfaction of those working-from-home in relation to work - life boundaries, before and during the quarantine period, in a country that just started to experiment remote working. I employ data from WFH (Voicu et al. 2020), a project carried out in Romania. The main idea of the project was to combine self-reported opinions and attitudes with photo elicitation based on visual analysis of the working space. In other words, researchers intended to visualize the working-space used at home, while collecting information on personal representations on work-life balance, expectations from work, assessments of personal situation, etc. In other words, the research combines survey data with pictures of the working-space from home. The latter allows assessing the overlapping between work and other personal spaces, including family, children, hobby, etc. The authors began to investigate the issue before pandemic, with research devoted to what remotely work implies for individuals' work - life balance. Two waves of an online survey were carried out, in 2018 and in April 2020 - during lockdown. The first wave included 223 respondents. The second, 345. Both samples were non-probabilistic, with recruitment of respondents based on personal networks, snowballing, and Facebook adds. Despite non-probabilistic samples, the data has the high advantage to allow comparing before and during-pandemics. While controlling basic status traits, including the number of children, other caring responsibilities, education, and percentage of hours worked from home in total working hours, one can depict relations between variables, and overcome the disadvantage of a non-representative sampling. In the first wave of the project, HBW was experienced as a work alternative by respondents who used to work from home at least a part of the time. The second wave also collected data from employees with previously limited or no experience of teleworking before COVID-19, in same isolated cases overlapping 
with respondents coming from the first wave. However, this time, the HBW was a forced experience, triggered by the lockdown. The effects of the pandemic are expected to change the way people relate to their WLB. To figure out, I chose to explore the respondent's levels of job satisfaction.

Job satisfaction is measured on 10-points scale, asking for "How satisfied are with your job?". I used it as an overall indicator for work-related wellbeing. This allows comparing the situation before and during COVID-19 pandemic times. Following the mainstream HBW literature, I assume as first theoretical hypothesis that those who are working from home to have a greater level of job satisfaction, compared to their office workers counterparts (H1). Furthermore, I expect that during the COVID-19 pandemic time, when working at home was a forced experience, the level of job satisfaction will gradually decrease, depending on the duration of exposure to telework, measured by total number of hours worked from home (H2). I also expect job satisfaction during lockdown to have various effects among teleworkers through interaction with other independent variables, such as age, marital status, and the number of dependent children in the household (H3).

Table no. 1 describes all the variables used in the analysis.

Table no. 1

Descriptive statistics for variables used in the analyses**

\begin{tabular}{|l|c|c|c|c|}
\hline Variable & Min & Max & Mean 2018 & Mean 2020 \\
\hline Job satisfaction & 1 & 10 & 7.51 & 7.57 \\
\hline Income (euro) & 0 & 15000 & 1031.9 & 1618.8 \\
\hline Gender (female=1) & 0 & 1 & $75 \%$ & $71 \%$ \\
\hline Education level & & & & \\
\hline post-secondary or less & 0 & 1 & $7.7 \%$ & $2.2 \%$ \\
\hline BA & 0 & 1 & $32.7 \%$ & $32.6 \%$ \\
\hline MS & 0 & 1 & $40.4 \%$ & $49.7 \%$ \\
\hline PhD & 0 & 1 & 19.2 & $15.5 \%$ \\
\hline Marital status & & & & \\
\hline Single & 0 & 1 & $24 \%$ & $26.7 \%$ \\
\hline Married & 0 & 1 & $46.2 \%$ & $45.5 \%$ \\
\hline Partnership & 0 & 1 & $20.2 \%$ & $21.6 \%$ \\
\hline Divorced/ Separated/ Widow & 0 & 1 & $9.5 \%$ & $6.1 \%$ \\
\hline No of children & 0 & 2 & 0.6 & 0.5 \\
\hline Age & 20 & 79 & 35.1 & 36.0 \\
\hline Weekly hours worked & 1 & 168 & 45.4 & 36.5 \\
\hline Weekly hours worked from home & 1 & 168 & 26.2 & 34.7 \\
\hline Household size & 0 & 8 & 2.59 & 2.42 \\
\hline Weekly hours worked before COVID-19 & 0 & 90 & - & 37.1 \\
\hline Dedicated working spaces & 0 & 1 & $81 \%$ & $85 \%$ \\
\hline
\end{tabular}

* WFH 2018/2020 database.

** Data are based on respondents' raw responses that may reflect their under/overestimates. To avoid reporting errors I used the data exactly as it was collected. 
One may observe that some respondents estimated their working time at 168 hours per week. Such overestimations naturally occur when people are asked to point out exact figures. Two perspectives are to be taken into consideration here. On the one hand, given that all figures are subjectivelly assessed, one cannot be sure that any of the figures in the dataset are correct. Some are probably underestimated, some are overestimated. Since one cannot tell for each respondent whether the answers go up or down with respect to the exact number, all these differences to reality go in subsequent models into the error term. On the other hand, in the case of this research note, only three cases indicate a working time larger than 90 hours per week. In the following I will use all cases regardless of indicated working time, then I rerun all analyses, excluding these cases, as robustness check. All results remain unchanged, proving that the models are stable and robust to such measurement errors. This is in line with findings reported by Jacobs (1998), who shows that self-reported data on hours usually worked per week tend to be overestimated, but errors are randomly distributed within the sample. Even more, recent research shows that workweek bias is small (Frazis and Stewart 2014).

In terms of method, I run regression models, with controls for basic sociodemographic and work-related characteristics, that allow disentangling the effects of variables of interest on job satisfaction. As mentioned in the description of the sample, this also overcomes the biases given the overqualified, feminized, younger sample (see Table no. 1). Controls for data collecting in 2018 and 2020 were added to stress the changes between the waves. Interaction effects between variables, such as age, gender, education, and percentage of hours worked from home in total working hours, before and during pandemic, the number of children, household size and dedicated working space from home, were included in the following six regression models, as Table no. 2 shows. Model 1 includes as predictors income, gender, education level, marital status, number of children, age, weekly hours worked from any location, weekly hours worked from home based on combined data from both waves. Model 2 tests for a quadratic dependency on weekly hours worked from home and education. Similar non-linear effects are modelled in model 3 with respect to number of children, and in Model 4 for age. The extended version of the first three models also adds other confounders, including household size, total weekly hours worked from any location before pandemic and dedicated working space from home (models 5 and 6). All models include interaction effects with the moment of data collection (before or during the pandemic).

In the following, the reported analyses refer to the samples, and cannot be extended to the whole population of individuals working from home. However, I also report significance levels to stress the most relevant effects depicted. 


\section{FINDINGS. JOB SATISFACTION AMONG HOME-BASED TELEWORKERS IN ROMANIA}

It is worth observing that a national representative sample lead to a point estimate of job satisfaction of 7.5 in 2016 (EQLS 2016), while a large sample in the web survey of Eurofound carried out in July 2020 round, indicated that $70.8 \%$ were satisfied with their quality of their work done from home. With the 2018 nonprobabilitstic WFH sample, job satisfaction had an average of 7.51 , with a $95 \%$ confidence interval of 7.01 to 8.02 . In 2020 , the value was 7.57 (95\% CI: 7.28 respectively 7.87). The means are virtually the same. In other words, both for 2018 and 2020, respondents working from home in the WFH sample were as satisfied as compared to the estimate resulting from the national sample in 2016. However, the comparison is not appropriate due to differences in the structure of the samples, so that multivariate analysis is necessary, as I do in the remainder of this section. This might be a simple effect of the way in which the WFH samples were drawn.

Table no. 2 depicts the results of the regression models. It turns out that income has no impact on the dependent variable. The impact of gender is negative for being a woman in all models, but it turns significant only in the last two models. On average, women are less satisfied, according to models 5 and 6 , with 0.6-0.8 points difference on the 10-point scale of job satisfaction. This is quite high, considering the average level of job satisfaction. Results can be interpreted through those different time periods according to the "exploitation model", Romanian society having traditional set-up about gender roles division within households. For example, women working from home had to combine the paid work with unpaid work (burden of responsibilities such as childcare and housing responsibilities). During the pandemic, when all the members from the household begun to work or stay at home together, the unpaid work responsibility maybe have been split between more individuals, but according to the negative outcome from being a woman coming from all the regression models, the main responsible member for doing the unpaid work is the women from the household. Another possible scenario could be the fact that during the lockdown, sharing the space within the same household (in some cases the size of the household could play an important role) added extra stress on the shoulder of women when working from home together with the rest of the family. At the same time, in the relevant cases, this applied to the online education of the children. Under these circumstances, during the quarantine period the gender differences increased by a small increment, which could explain why the job satisfaction, even when negative, was not significant for the first four models. 
Table no. 2

Regression models of Job satisfaction

\begin{tabular}{|c|c|c|c|c|c|c|}
\hline Variables used in models & (1) & $(2)$ & (3) & (4) & (5) & $(6)$ \\
\hline Income (euro) & 0.00 & 0.00 & 0.00 & 0.00 & 0.00 & 0.00 \\
\hline Woman & -0.33 & -0.33 & -0.32 & -0.37 & $-0.62^{+}$ & $-0.78^{*}$ \\
\hline Education: BA & $-2.08^{* * * *}$ & $-1.66^{*}$ & $-2.00^{* * *}$ & $-2.13^{* * *}$ & $-2.33^{* * *}$ & $-2.59^{* * *}$ \\
\hline Education: MS & $-2.57^{* * * *}$ & $-1.60^{*}$ & $-2.46^{* * * *}$ & $-2.53^{* * *}$ & $-2.93^{* * *}$ & $-3.22^{* * * *}$ \\
\hline Education: $\mathrm{PhD}$ & $-1.92^{* * *}$ & -1.08 & $-1.92^{* * * *}$ & $-2.01^{* * *}$ & $-2.44^{\text {**** }}$ & $-2.58^{* * * *}$ \\
\hline Married & 0.29 & 0.12 & 0.16 & 0.36 & 0.72 & $0.80^{+}$ \\
\hline Partnership & 0.22 & 0.14 & 0.20 & 0.25 & 0.76 & $\mathbf{0 . 8 9}^{+}$ \\
\hline Divorced/Separated/Widow & -0.21 & -0.31 & -0.26 & -0.35 & 0.24 & 0.44 \\
\hline One child & -0.03 & 0.01 & 0.35 & 0.45 & 0.03 & 0.08 \\
\hline $2+$ children & 0.31 & 0.36 & -0.08 & $\mathbf{0 . 9 6}^{+}$ & 0.78 & 0.91 \\
\hline Age & -0.24 & -0.01 & -0.01 & -0.04 & $-0.33^{+}$ & $-0.39^{*}$ \\
\hline Age Squared & 0.00 & & & -0.00 & $0.00^{*}$ & $0.00^{*}$ \\
\hline Lives in Romania/ Moldova & 0.43 & 0.39 & 0.42 & 0.33 & 0.01 & 0.03 \\
\hline Weekly hours worked & $0.02^{+}$ & 0.01 & 0.01 & 0.01 & $\mathrm{0.04}^{+}$ & $0.05^{*}$ \\
\hline WFH2020-April & 0.56 & $1.17^{+}$ & 0.34 & 3.76 & & \\
\hline $\begin{array}{l}\text { Weekly hours worked from } \\
\text { home }\end{array}$ & -0.01 & -0.01 & -0.02 & -0.01 & -0.01 & -0.01 \\
\hline $\begin{array}{l}\text { WFH2020-April \# Weekly } \\
\text { hours worked from home }\end{array}$ & -0.01 & & & & & \\
\hline WFH2020-April \# BA & & -0.48 & & & & \\
\hline WFH2020-April \# MS & & -1.20 & & & & \\
\hline WFH2020-April \# PhD & & -1.19 & & & & \\
\hline $\begin{array}{l}\text { Weekly hours worked from } \\
\text { home Squared }\end{array}$ & & 0.00 & 0.00 & 0.00 & -0.00 & -0.00 \\
\hline WFH2020-April \# one child & & & -0.46 & & & \\
\hline WFH2020-April \# 2+ children & & & 0.55 & & & \\
\hline WFH2020-April \# age & & & & -0.24 & & \\
\hline WFH2020-April \# age squared & & & & $0.00^{+}$ & & \\
\hline Household size & & & & $-0.35^{+}$ & -0.30 & -0.24 \\
\hline $\begin{array}{l}\begin{array}{l}\text { Pre-pandemic Weekly hours } \\
\text { worked }\end{array} \\
\end{array}$ & & & & & $-0.04^{*}$ & $-0.04^{*}$ \\
\hline $\begin{array}{l}\text { Dedicated working space at } \\
\text { home }\end{array}$ & & & & & & $\mathbf{0 . 7 3}^{+}$ \\
\hline Constant & $13.66^{* * *}$ & $8.85^{3 * * \pi}$ & $9.28^{* * *}$ & $11.62^{*}$ & $17.15^{* * * *}$ & $18.31^{* * * 2}$ \\
\hline Observations & 155 & 155 & 155 & 154 & 109 & 106 \\
\hline Pseudo $R^{2}$ & & & & & & \\
\hline
\end{tabular}

${ }^{+} p<0.10,{ }^{*} p<0.05,{ }^{* *} p<0.01,{ }^{* * *} p<0.001$.

The number of weekly worked hours increases job satisfaction in all models and is significant in half of them. Considering the range of reported hours worked, which ranges from 1 to 168 , the effect of a tenth of this scale (some 17 hours worked) is an increase in job satisfaction of .17-.75, depending on the considered 
model. Results are quite strong, but one needs to consider that working 168 hours per week is unrealistic, since it means working all-time, with no breaks, not even for food, sleep, or self-care. Beyond the inaccuracy in reporting of the respondents, if we consider a maximal number of worked hours of half of the reported maximum: 84 hours, the argument related to the effect of worked hours remains quite strong. The effect is depicted in Figure 1. In a more restrictive but realistic scenario, a difference of a quarter of the legal working week (40 hours, meaning that a quarter is 10 hours) lead to a decrease in job satisfaction by 4 points. While job satisfaction has a standard deviation of about 1.8 in both 2018 and 2020, the decrease is not large, but it is not negligible either.

Figure 1

Marginal effects of weekly hours worked from home on job satisfaction, before and during COVID-19 pandemic

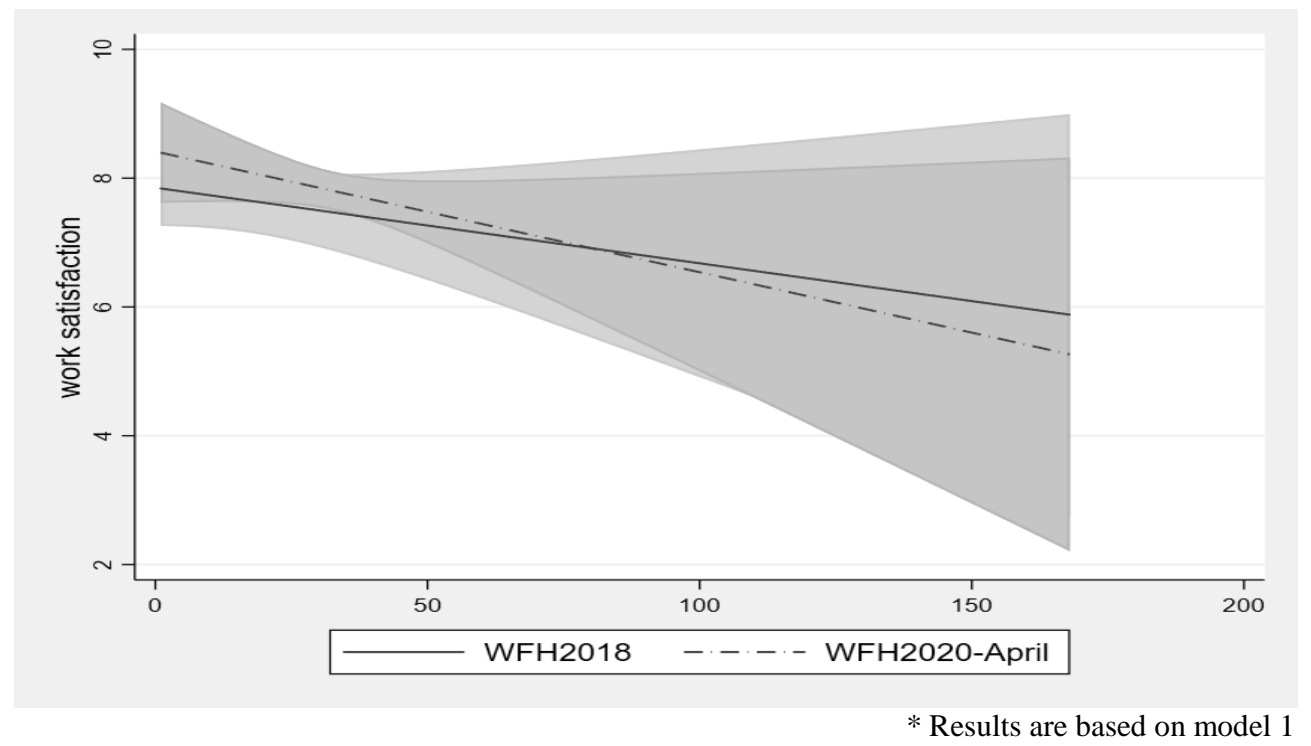

Marital status brings almost no effect on job satisfaction. Only in model 6 is there a visible difference between being in a couple versus being single. During the pandemic, being in couple lead to a 0.89 points higher job satisfaction.

The impact of age proved to be different in pandemic times as compared to 2018, as illustrated by the marginal effects depicted in Figure 2. Before the pandemic, the job satisfaction of those who worked from home decreased with age. The younger ones working from home were more satisfied, as compared to older ones in the same situation. Instead, during the quarantine, the relation was quadratic: satisfaction with work decreased with age, as it did before pandemic, but 
increased constantly with age for people over 40 years, after a plateau observed at 35-40 years of age. Most likely, before the pandemic, working from home was associated with job insecurity, which is less bearable to older ages. During pandemic, since everyone or almost everyone was working from home, extraWLB-related-benefits changed the dependency, and older cohorts derived more satisfaction, and even increased it over the pre-pandemic levels.

Figure 2

Marginal effects of age on job satisfaction before and during COVID-19 pandemic

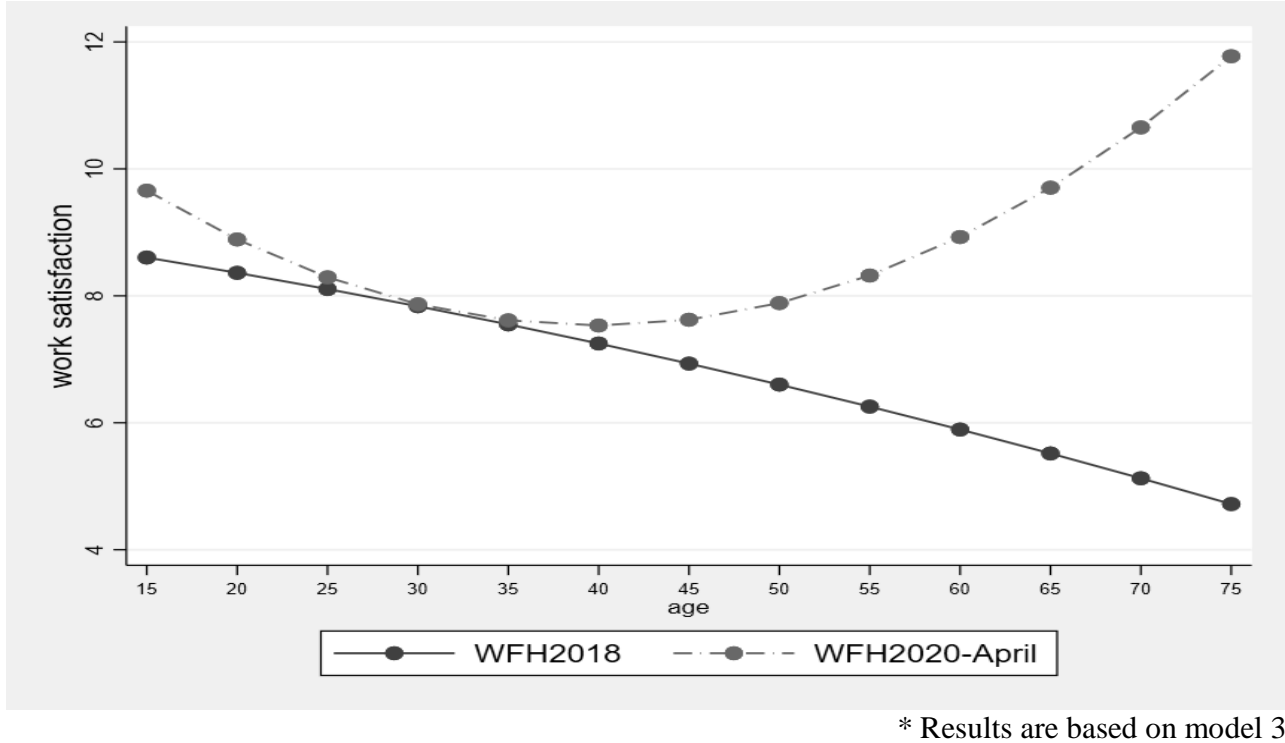

Also, comparing both waves of data collection, as Figure 3 shows, a relation was found between job satisfaction and level of education. Before the pandemic, less educated respondents were more satisfied working from home. Probably because less educated individuals are more likely not to work from home, compared to the more educated ones for which telework is a customary mode of working for many of them. Furthermore, knowledge workers have the greater probability to work remotely, regardless of location, because they are highly educated and have the necessary skills to carry out their digital work. As compared to the general population, the survey respondents tend to have a higher education, due to the selection bias induced by having had the survey distributed on social media through the personal networks of the researchers. This led to the assumption that respondents are likely to be employed in knowledge work jobs (e.g., employees working in IT, finance, and research) for which are already required tertiary qualifications. 
Figure 3

Marginal effects of educational level on job satisfaction before and during COVID-19 pandemic

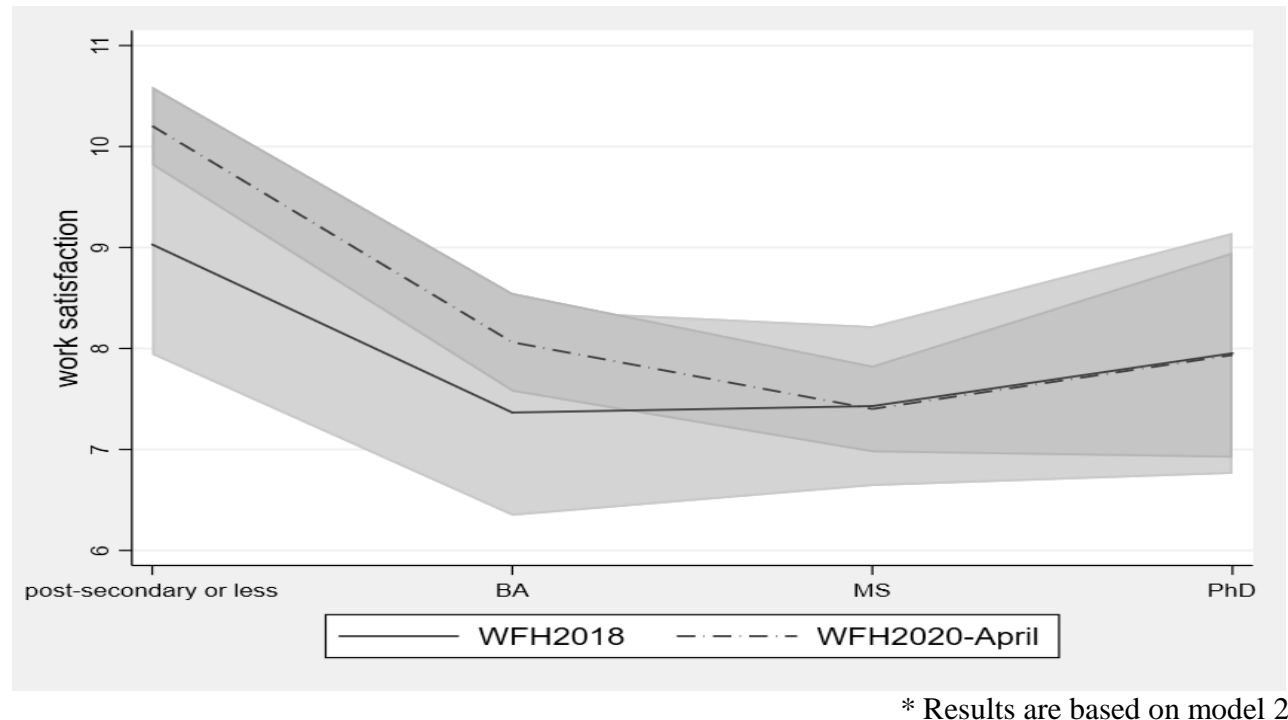

Figure 4

Marginal effects of children' number on job satisfaction before and during COVID-19 pandemic

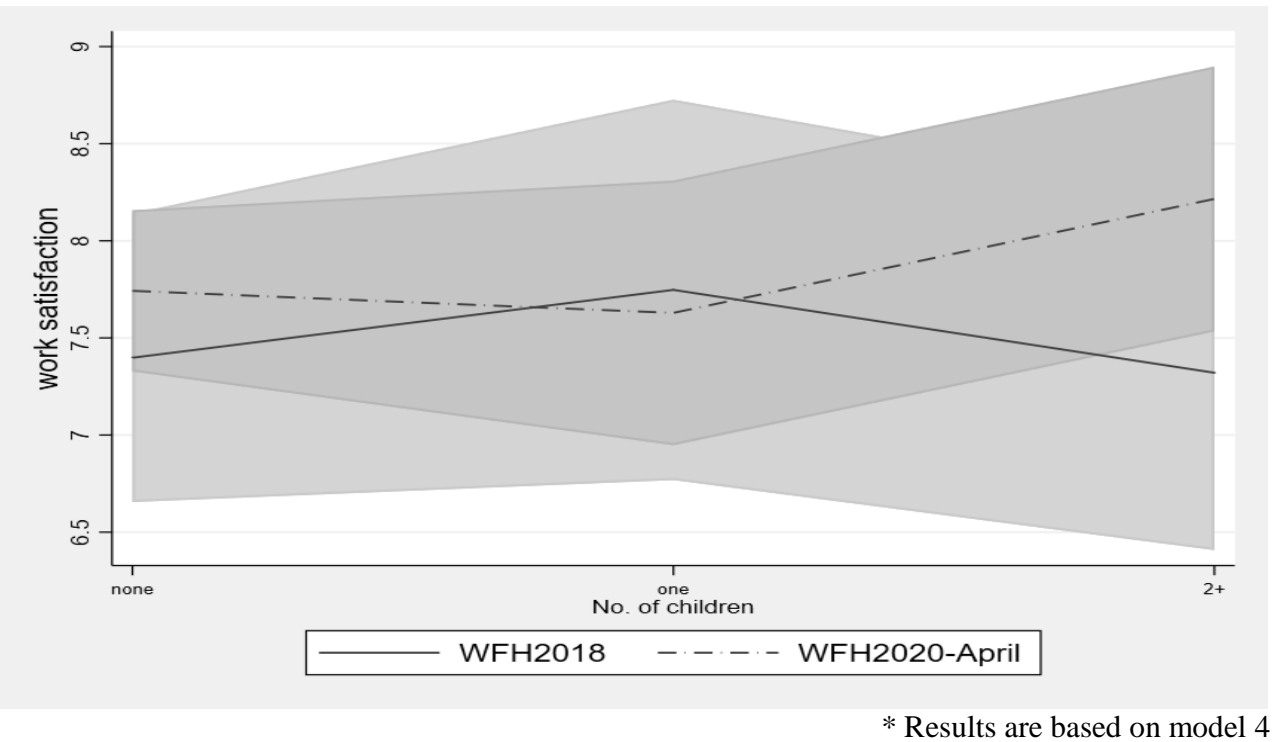


Contrary to common stereotypes, having children was not a game changer with respect to job satisfaction during the pandemic, according to Figure 4. Only in model 4 , having more children leads to a 0.96 points higher job satisfaction, which can mean that children are a resource both for increasing the job satisfaction and WLB. For future analysis, it is interesting to find out why having more children leads to an increase in job satisfaction, and possibly to an increase in general life satisfaction.

Household size tends to have a negative effect on job satisfaction. Before the pandemic it had not significant effects, but during the quarantine, as Model 4 reveals, the level of job satisfaction decreased with 0.35 points under the interaction effect of the household size. Furthermore, having a dedicated working space at home could be a game changer for increasing job satisfaction, leading to a better WLB. Model 6 depicts that those working from home and having a dedicated working space increase with 0,73 the job satisfaction level.

It is likely that at the beginning of the pandemic, in April 2020, life satisfaction and optimism were not yet affected by the lockdown, thus explaining why even job satisfaction did not vary much. For both waves, job satisfaction of those who work from home is not influenced by income, marital status, or number of children, maybe because during the collection of the data, not enough time had passed for these effects to be recorded.

\section{DiscuSSION AND CONCLUSIONS}

The findings revealed a complex picture of the embededness of job satisfaction in the pre- and during-pandemic conditions, as seen below in Table no. 3 . Both for 2018 and 2020, respondents working from home in the WFH sample were as satisfied as the estimate resulting from the national sample in 2016. However, given potential self-selection into the WFH samples, the result might be subject to distorsion, and multivariate analysis was used for the remaining hypotheses. The link between the amount of time devoted to working from home and job satisfaction is subject to non-linear variation: a greater job satisfaction gradually increases with hours worked from home, but after more than 40 weekly hours worked, job satisfaction decreases sharply. Above all, during the pandemic, those who used to work longer before were more dissatisfied with working from home. Among WFH respondents, the total amount of work is a game changer, being both an increaser (before pandemic) or a source of decrease for job satisfaction. During the lockdown, the effects are felt in the case of working over 40 hours per week, which strongly hinders job satisfaction.

The job satisfaction of those working from home occasionally, increases depending on being in a couple, weekly working hours (the more they have to work, the higher their job satisfaction), and having a dedicated working space at home. Women proved to be less satisfied than men, household size had a negative 
effect, university graduates were more dissatisfied working from home; in terms of age, the older respondents felt less satisfied WFH before pandemics, but the relationship changed, and young adults along with those over 50 were more satisfied during COVID-19 lockdown. For both waves, the job satisfaction of those who work from home was not influenced by income, marital status, or number of children. Overall findings showed that a major effect caused by COVID-19 crisis sharpened social inequalities and increased the likelihood of gender disparities. According to all models measuring job satisfaction, being a woman had a negative impact, which could mean that women experienced a disproportionate impact of WFH.

Tabel no. 3

Framework of positive/ negative outcomes on job satisfaction among home-based teleworkers

\begin{tabular}{|l|c|c|}
\hline \multicolumn{1}{|c|}{ Indicators } & $\begin{array}{l}\text { Models that include only } \\
\text { the 2020 sample }\end{array}$ & $\begin{array}{c}\text { Models that include } \\
\text { both 2020 and 2018 }\end{array}$ \\
\hline Age & $+(<25$ y.o $)$ & $\begin{array}{c}+(<25 ;>35 \text { y.o }) \\
-(>25-<35 y .0)\end{array}$ \\
\hline Gender (Woman) & - & No effects \\
\hline Education (Tertiary) & - & - \\
\hline Marital status (being in a couple) & + & No effects \\
\hline 2+children & No effects & + \\
\hline More weekly hours worked & + & $+/-$ (over 40 hours $)$ \\
\hline Household size & - & No effects \\
\hline Having dedicated WFH space & + & Not included \\
\hline
\end{tabular}

* Results based on regression models from WFH 2018/2020 survey.

Notwithstanding, this study has its limits. First of all, the analysis was based on a non-probabilistic sample, thus the study does not provide representative results for the entire Romanian population working from home. Secondly, as compared to the general population, the survey respondents tend to be overqualified, feminized, younger, due to the selection bias induced by having had the survey distributed on social media through the personal networks of the researchers. However, the main findings pictured above allow depicting the situation of working from home and its pandemic dynamics in Romania.

Using longitudinal data coming from WFH survey, allowed making comparisons between both waves of data collection, before and during the pandemic. Future research should include more analyzes, in order to explore differences in what WFH means across gender roles, professions, or between countries. Cross-sectional studies are needed to uncover contextual drivers of jobsatisfaction in the case of those working from home. Comparative studies should also be able to investigate whether the results are generalizable to other societies. Increased attention should be paid to the choice of countries, depending on their 
level of development. Choosing societies that vary significantly, for example in terms of gender divisions in labour, can provide more in-depth results about the impact of working from home on job satisfaction. The general expectation is that there will be significant differences between Eastern European countries, compared to more advanced Western societies. Also, it will be interesting to see whether the long-term effects observed in this study are maintained, thus planning a third wave of WFH survey after the COVID-19 could be a future research direction. Targeting a larger sample of people that started to work from home mainly after COVID-19 outbreak, or at least heavily increased this practice, could offer the possibility to widen enough the control group to contrast the original panel to newcomers in the working-from-home universe.

Findings have practical value for different stakeholders. Home-based workers, employers, and policy makers could use the results in such a way that they can simultaneously boost quality of life and work productivity and make the new working arrangements functional. The analyzed results should help teleworkers to better choose from among the diversity of work - life arrangements in order to meet both their family and workplace demands.

Employers may observe the decreasing trend in job satisfaction with the amount of worked hours and may want to prevent negative effects on work productivity by providing targeted programs to those who work more hours. Employees and labour unions should take into consideration renegotiation of their working schedule, for a better adjustment with their family needs. In an age when work is increasingly decentralized, the number of worked hours should matter less, especially in situations where work is done from home. In the absence of supervising control, rewarding work should be evaluated by outcomes, and not so much by the number of hours worked, that is both employers and employees could discuss product-based working contracts instead of workload-based ones. This also takes into account the level of workload that can eventually lead to longer hours worked, but here special attention should be paid to the autonomy that the employee has on work tasks, depending on his career level and job position. During the pandemic, those aged 35-45 showed the lowest levels of job satisfaction. These employees could be helped by more focused policies on the needs of their life's stage to prevent conflicts that may arise between work life and family demands. The fact that age, but also the amount of work, really count in job satisfaction, especially in the case of working from home, should signal to employers to better adapt their working conditions and human resource policies.

Last but not least, the whole society could benefit through such research to provide a better coping strategy for individuals and workplaces with pandemics and with the subsequent cultural and collective traumas. Understanding the variety of short- and medium-term effects of pandemic gives policy makers the chance to take future action measures to prevent/mitigate potential long-term effects, and adjust their strategy, if similar situations will be repeated in the future. 


\section{REFERENCES}

Aguilera, A., Lethiais, V., Rallet, A., and Proulhac, L. 2016. "Home-based telework in France: Characteristics, barriers, and perspectives". Transportation Research Part A: Policy and Practice 92:1-11. https://doi.org/10.1016/j.tra.2016.06.021.

Allen, T. D., Golden, T. D., and Shockley, K. M. 2015. How effective is telecommuting? Assessing the status of our scientific findings. Psychological Science in the Public Interest 16:40-68.

Bentley, K., and Yoong, P. 2000. "Knowledge work and telework: An exploratory study". Internet Research 10: 346-356.

Brief, A. P., and Weiss, H. M. 2002. "Organizational behavior: Affect in the workplace". Annual Review of Psychology,53, 279-307.

Caillier, J. G. 2012. "The impact of teleworking on work motivation in a U.S. federal government agency". American Review of Public Administration 42: 461-480.

Charalampous, M., Grant, C. A., Tramontano, C., and Michailidis, E. 2019. "Systematically reviewing remote e-workers' wellbeing at work: a multidimensional approach". European Journal of Work and Organizational Psychology, 28(1):51-73. https://doi.org/10.1080/1359432X.2018.1541886.

Chesley, N. 2010. "Technology use and employee assessments of work effectiveness, workload, and pace of life". Information, Communication \& Society 13: 485-514.

Chesley, N. 2014. "Information and communication technology use, work intensification and employee strain and distress". Work, Employment and Society 28:589-610.

Crosbie, T., and Moore, J. 2004. "Work-life Balance and Working from Home". Social Policy \& Society 3(3): 223-233 DOI:10.1017/S1474746404001733.

De Menezes, L. M., and Kelliher, C. 2011. "Flexible working and performance: A systematic review of the evidence for a business case". International Journal of Management Reviews 13: 452474.

Diener, E., Oishi, S., and Lucas, R. E. 2003. "Personality, culture, and subjective wellbeing: Emotional and cognitive evaluations of life". Annual Review of Psychology 54: 403-425.

Eddleston, K. A., and Mulki, J. 2015. "Toward Understanding Remote Workers' Management of Work-Family Boundaries: The Complexity of Workplace Embeddedness". Group and Organization Management 42(3): 346-387. https://doi.org/10.1177/1059601115619548.

European Quality Life Survey. 2016. accessed on January 19: https://www.eurofound.europa.eu/data/european-quality-of-life-survey.

Eurofound and the International Labour Office. 2017. "Working anytime, anywhere: The effects on the world of work". Publications Office of the European Union, Luxembourg, and the International Labour Office, Geneva. Retrieved from Eurofound Publications websitehttps://www.eurofound.europa.eu/publications.

Eurofound. 2020. "Living, working and COVID-19, COVID-19 series", Publications Office of the European Union, Luxembourg. Retrieved on https://www.eurofound.europa.eu/sites/default/files/ef_publication/field_ef_document/ef20059 en.pdf.

Fana, M., Tolan, S., Torrejón, S., Urzi Brancati, C., Fernández-Macías, E. 2020. "The COVID confinement measures and EU labour markets", EUR 30190 EN, Publications Office of the European Union, Luxembourg; doi:10.2760/079230, JRC120578, retrieved on https://publications.jrc.ec.europa.eu/repository/bitstream/JRC120578/jrc120578_report_covid_ confinement_measures_final_updated_good.pdf.

Frazis, Harley and J. Stewart. 2014. "Is the workweek really overestimated." Monthly Labor Review 137: 1-15.

Feng, Z., and Savani, K. 2020. "Covid-19 created a gender gap in perceived work productivity and job satisfaction: implications for dual-career parents working from home". Gender in Management, 35(7/8):719-736. https://doi.org/10.1108/GM-07-2020-0202. 
Felstead A., Jewson N., Phizacklea A., and Walters S. 2002." Opportunities to work at home in the context of work-life balance". Human Resource Management Journal 12: 54-76.

Gajendran, R. S., and Harrison, D. A. 2007. "The good, the bad, and the unknown about telecommuting: Meta-analysis of psychological mediators and individual consequences". Journal of Applied Psychology 92:1524-1541.

Gambles, R., Lewis, S. and Rapoport, R. 2006. "The Myth of WLB: The Challenge of Our Time for Men, Women and Societies". Chichester: Wiley.

Greenhaus, J.H., Collins, K.M. and Shaw, J.D. 2003. "The Relation between Work - Family Balance and Quality of Life". Journal of Vocational Behavior 63:510-531. http://dx.doi.org/10.1016/S0001-8791(02)00042-8.

Golden, T.D. 2009. “Applying Technology to Work: Toward a Better Understanding of Telework". Organization Management Journal6 4: 241-250.

Golden, T. D., and Veiga, J. F. 2005. "The impact of extent of telecommuting on job satisfaction: Resolving inconsistent findings". Journal of Management 31: 301-318.

Jacobs, J. 1998. "Measuring time at work: are self-reports accurate?" Monthly Labor Review 121: 4253.Judge, T. A., Ilies, R. 2004. "Affect and job satisfaction: A study of their relationship at work and at home". Journal of Applied Psychology 89: 661-673.

Hartig, T., Kylin, C., and Johansson, G. 2007. "The telework tradeoff: Stress mitigation versus constrained restoration”. Applied Psychology: An International Review 56: 232-253.

Hilbrecht, M., Shaw, S. M., Johnson, L. C., and Andrey, J. 2008. "I'm Home for the Kids": Contradictory Implications for Work-Life Balance of Teleworking Mothers. Gender, Work and Organization 15( 5): 454-476.

Hilbrecht, M., Shaw, S. M., Johnson, L. C., and Andrey, J. 2013. "Remixing work, family, and leisure: teleworkers' experiences of everyday life". New Technology, Work and Employment 28(2): 130-144

Hislop, D. and C. Axtell 2007. "The neglect of spatial mobility in contemporary studies of work: the case of telework". New Technology, Work and Employment 22(1): 34-51.

Hislop, D. and C. Axtell. 2009. "To Infinity and Beyond? Workspace and the Multi-location Worker'. New Technology, Work and Employment 24(1): 60-75.

Hornung, S., and Glaser, J. 2009. "Home-based telecommuting and quality of life: Further evidence on an employee-oriented human resource practice”. Psychological Reports 104: 395-402.

Hynes, M. 2014a. "Telework Isn't Working: A Policy Review. In the Economic and Social Review 45(4): 223-233. https://doi.org/10.1017/s1474746404001733.

van der Lippe, T., Lippényi, Z. 2020. Beyond Formal Access: Organizational Context, Working from Home, and Work-Family Conflict of Men and Women in European Workplaces. Social Indicators Research 151: 383-402. https://doi.org/10.1007/s11205-018-1993-1.

Kelliher, C., and Anderson, D. 2010. "Doing more with less? Flexible working practices and the intensification of work". Human Relations 63: 83-106.

Kurowska, A. 2018. "Gendered Effects of Home-Based Work on Parents' Capability to Balance Work with Non-work: Two Countries with Different Models of Division of Labour Compared". Social Indicators Research 151(2): 405-425. doi:10.1007/s11205-018-2034-9.

Maitland, A., and Thomson, P. 2014. "Future work (expanded and updated): Changing organizational culture for the new world of work". London, UK: Springer.

Marsh, K., and Musson, G. 2008. "Men at work and at home: Managing emotion in telework" Gender, Work, and Organization 15: 31-48.

Maruyama, T., Hopkinson, P. G., and James, P. 2009. "A multivariate analysis of work-life balance outcomes from a large-scale telework programme". New Technology, Work and Employment 24: 76-88

Moe, K., and Shandy, D. 2010. "Glass ceilings \& 100-hour couples: What the opt-out phenomenon can teach us about work and family". Athens, GA: The University of Georgia Press. 
Morganson, V. J., Major, D. A., Oborn, K. L., Verive, J. M., and Heelan, M. P. 2010. “Comparing telework locations and traditional work arrangements: Differences in work-life balance support, job satisfaction, and inclusion". Journal of Managerial Psychology 25: 578-595.

Parasuraman, S., and Greenhaus, J. H. 2002. "Toward reducing some critical gaps in work-Family research". Human Resource Management Review 12: 299-312.

Powell, A., and Craig, L. 2015. "Gender differences in working at home and time use patterns: evidence from Australia”. Work, Employment and Society 29(4): 571-589.

Russell, H., O’Connell, P. J., and McGinnity, F. 2009. "The impact of flexible working arrangements on work-life conflict and work pressure in Ireland". Gender, Work and Organization 16: 7397. https://doi.org/10.1177/0950017014568140.

Shamir, B. and Salomon, I. 1985. "Work-at-Home, and the Quality of Working Life". The Academy of Management Review 10(3): 455-464.

Saltmarsh, S. and Randell-Moon, H., 2015. "Managing the risky humanity of academic workers: risk and reciprocity in university work-life balance policies". Policy Futures in Education, 13 (5): 662-682 doi:10.1177/1478210315579552.

Sardeshmukh, S. R., Sharma, D., and Golden, T. D. 2012. "Impact of telework on exhaustion and job engagement: A job demands and job resources model". New Technology, Work and Employment 27: 193-207.

Sullivan, C., and Lewis, S. 2001. "Home-based telework, gender and the synchronization of work and family: Perspectives of teleworkers and their co-residents". Gender, Work and Organization 8(2): 123-145.

Ter Hoeven, C. L., and Van Zoonen, W. 2015. "Flexible work designs and employee wellbeing: Examining the effects of resources and demands". New Technology, Work and Employment 30: 237-255

Tietze, S., and Nadin, S. 2011. "The psychological contract and the transition from office-based to home-based work". Human Resource Management Journal 21: 318-334.

Tietze, S., and Musson, G. 2005. "Recasting the home-work relationship: A case of mutual adjustment?" Organization Studies 26:1331-1352.

Van Horn, J. E., Taris, T. W., Schaufeli, W. B., and Schreurs, P. J. 2004. "The structure of occupational wellbeing: A study among Dutch teachers". Journal of Occupational and Organizational Psychology 77: 365-375.

Vega, R. P., Anderson, A. Jveg., and Kaplan, S. A. 2015. “A within-person examination of the effects of telework". Journal of Business and Psychology 30: 313-323.

Virick, M., DaSilva, N., and Arrington, K. 2010. "Moderators of the curvilinear relation between extent of telecommuting and job and life satisfaction: The role of performance outcome orientation and worker type". Human Relations 63: 137-154.

Voicu, B. 2015. "Priming Effects in Measuring Life Satisfaction", Social Indicators Research. 124(3):993-1013.

Voicu, B., Neguț, A., Tufă, L., Glăvan, E., Florea, A., and Țălnar-Naghi, D. 2020. "Working from home 2.1 Cum s-a lucrat de acasă în carantină”, Report accessed on January 19: https://docs.google.com/viewer?a=v\&pid=sites\&srcid=ZGVmYXVsdGRvbWFpbnxycXNhcm 98Z3g6MjM2Zjg2OTc3NzY3ODBkMQ.

Wight, V. R., and Raley, S. B. 2009. "When home becomes work: work and family time among workers at home". Social Indicators Research 93(1): 197-202.

$B$ azată pe dezvoltarea TIC, telemunca reprezintă un fenomen de schimbare rapidă (Eurofound 2017) ce a provocat numeroase dezbateri cu privire la modul în care influențează viața oamenilor (Allen, Golden și Shockley 2015; Golden 2009), permițând acum acestora să lucreze de oriunde și oricând prin intermediul laptopurilor, tabletelor și smartphone-urilor (Maitland and Thomson 2014). Declanșarea 
crizei COVID-19 a accelerat schimbările sociale și a dus la o intrare forțtă a întregii populații în telemuncă. Schimbarea accelerată $s$-a produs în special in țările cu incidență pre-pandemică scăzută în ceea ce privește experiența de a lucra de acasă, cum este cazul României. Folosind date longitudinale provenite dintr-un sondaj online despre munca de acasă (Voicu et al. 2020), efectuat în 2018 și în timpul carantinei din primăvara lui 2020 în România, lucrarea își propune să exploreze satisfacția muncii în rândul celor care lucrează de acasă, în raport cu limitele echilibrului dintre viața profesională şi cea personală, inainte şi în timpul perioadei de carantină. Constatările sunt utile pentru o înțelegere mai profundă a modului în care noile aranjamente de lucru influențează percepțiile telelucrătorilor asupra calității vieții. Rezultatele indică faptul că, în timp ce inainte de pandemie, satisfacția la locul de muncă a celor care lucrau de acasă scădea odată cu vârsta respondentului (cel mai tânăr fiind mai mulțumit de munca de acasă), această tendintă s-a schimbat în timpul carantinei, iar satisfactia la locul de muncă a crescut exponențial pentru persoanele peste 40 de ani. In plus, a lucra mai multe ore inainte de pandemie este asociat cu scoruri mai mici de satisfacție la locul de muncă în timpul carantinei COVID-19.

Cuvinte-cheie: munca de acasă; satisfacția muncii; „WLB”, pandemie; telelucrători. 